\title{
Pengaruh Psikoedukasi terhadap Kecemasan Ibu Pre Operasi Kanker Payudara
}

\author{
Titi Astuti ${ }^{1}$, Rizki Azni Desvianti ${ }^{2}$, Merah Bangsawan ${ }^{3}$ \\ ${ }^{1,2,3}$ Jurusan Keperawatan, Politeknik Kesehatan Tanjungkarang, Indonesia \\ Email: astutititi7@gmail.com
}

\begin{abstract}
The Effect of Psychoeducation on The Anxiety of Preoperative Women with Breast Cancer. International Agency for Research on Cancer (IARC) in 2012, The incidence of cancer in women in Indonesia 134 per 100,000 population with the highest incidence in women is breast cancer of 40 per 100,000 . The problem that often arises before surgery is anxiety. The client's anxiety generates a psychosocial response. There is psychological therapy for preoperative patient anxiety treatment with psychoeducation. This study aims to determine the effect of psychoeducation on anxiety levels of patients preoperative breast cancer in RSUD DR. H. Abdul Moeloek Year 2018. Type of quantitative research method using quasi-experiment design with one group pretest design approach posttests design Sampling technique using purposive sampling technique as much as 30 respondents. The time of the study date of May 18, 2018, to June 30, 2018, in the Room of Roses RSUD DR. H. Abdul Moeloek Lampung Province. The data were collected using a self-Rating Anxiety Scale (SAS/ZSRAS) Zung questionnaire. Statistical test using t dependent Wilcoxon.
\end{abstract}

Keywords: Anxiety, Breast cancer, Psychoeducation

\begin{abstract}
Abstrak: Pengaruh Psikoedukasi terhadap Kecemasan Ibu Pre Operasi Kanker Payudara. International Agency for Research on Cancer (IARCH) tahun 2012, menyatakan Insidens kanker pada wanita di Indonesia 134 per 100.000 penduduk dengan insidens tertinggi pada wanita adalah kanker payudara sebesar 40 per 100.000 . Masalah yang sering timbul sebelum operasi adalah kecemasan. Terdapat terapi psikologis untuk penanganan kecemasan pasien pre operasi yaitu dengan psikoedukasi. Penelitian ini bertujuan untuk mengetahui pengaruh psikoedukasi terhadap tingkat kecemasan pasien pre operasi kanker payudara di RSUD DR. H. Abdul Moeloek Tahun 2018. Jenis penelitian metode kuantitatif dengan menggunakan desain quasi exsperiment dengan pendekatan desain one grup pretest postests design Teknik pengambilan sampel dengan menggunakan teknik purposive sampling sebanyak 30 responden. Waktu penelitian tanggal 18 Mei 2018 sampai 30 Juni 2018 di Ruang Mawar RSUD DR. H. Abdul Moeloek Provinsi Lampung. Pengumpulan data menggunakan kuesioner Zung self-Rating Anxiety Scale (SAS/ZSRAS). Uji statistik menggunakan Uji Wilcoxon Signed Ranks Test.Hasil penelitian terdapat perbedaan pengaruh psikoedukasi terhadap tingkat kecemasan pasien pre operasi kanker payudara $p$-value 0.000 . Peneliti menyarankan dari pihak Rumah Sakit mempertimbangkan menggunakan terapi psikoedukasi untuk mempersiapkan pasien kanker payudara menghadapi operasi dengan menggunakan Standar Operasional Prosedur yang ada.
\end{abstract}

Kata Kunci: Kanker payudara, Kecemasan, Psikoedukasi

\section{PENDAHULUAN}

Penyakit kanker merupakan penyakit yang bisa menyebabkan kematian pada wanita. Terdapat lima penyakit kanker tertinggi yang menyebabkan angka kejadian dan angka kematian pada wanita, yaitu terdiri dari kanker leher rahim, kanker payudara, kanker kulit, kanker rektum, dan kanker paru-paru. Diantara lima penyakit kanker tersebut angka kejadian dan angka kematian di dunia akibat kanker payudara menempati urutan pertama yang akhir-akhir ini semakin meningkat (Rasjidi, 2009).

Berdasarkan data dari American Cancer Society (2016) "Kanker payudara invasif didiagnosis sekitar 246.660 wanita dan 2.600 pria. Sebesar 61.000 kasus baru pada kanker payudara in situ didiagnosis pada wanita. Perkiraan kanker payudara di Amerika Serikat untuk 2017 adalah 252.710 kasus baru kanker payudara invasif akan didiagnosis pada wanita dan 63.410 kasus baru carsinoma in situ (CIS) akan didiagnosis (CIS adalah non-invasif dan 
merupakan bentuk paling awal dari kanker payudara (Najm, 2014 dalam Maretna, 2018) .

Prevalensi kanker payudara di Indonesia yaitu 0,5 per 1000 perempuan, sedangkan prevalensi kanker payudara di Provinsi Bali mencapai 0,6 per 1000 perempuan (Kemenkes RI, 2015, dalam Dyanti 2016).

Penderita kanker payudara di Provinsi Lampung cukup tinggi. Hal ini berdasarkan data yang ada dari Dinas Kesehatan Provinsi Lampung selama tahun 2014 terdapat penderita 2.119 kanker payudara dan 383 kasus kanker leher rahim (Profil Kesehatan Provinsi Lampung, 2015). Dari data Medical Record RSUD Dr. H. Abdul Moeloek Provinsi Lampung tahun 2017, kanker payudara masuk dalam daftar 10 besar penyakit rawat inap dan menduduki peringkat pertama sebagai daftar besar penyakit rawat inap. Jumlah pasien kanker payudara yang dirawat inap selama September 2017 sampai dengan Februari tahun 2018 sebanyak 331 orang.

Penanganan pasien kanker payudara paling banyak dengan tindakan medis atau operasi. Setiap jenis tindakan medis (operasi) dan pengobatan penyakit ini dapat menimbulkan masalah masalah fisiologis, psikologis, dan sosial pada pasien.

Hasil dari beberapa penelitian untuk pasien yang akan dilakukan tindakan operasi, masalah yang sering timbul adalah kecemasan. Pada tindakan medik operatif persiapan status somatik pasien umumnya telah dilakukan dengan baik terutama status kardio pulmonal, pemeriksaan laboratorium dan penunjang yang diperlukan. Sebaliknya persiapan status psikis sering kali dianggap tidak penting dan sering kurang menjadi perhatian padahal dapat mengoptimalkan hasil tindakan, bila status psikis dipersiapkan dan ditatalaksanakan dengan baik (Mansjoer, 2007).

Psikoedukasi dalam pelaksanaannya memberikan pendidikan kesehatan pada pasien baik yang mengalami penyakit fisik maupun ganguan jiwa yang bertujuan untuk mengatasi masalah psikologis yang dialami mereka. Penyakit fisik disini bisa berupa hipertensi, kanker, penyakit kulit, dan sebagainya. Gangguan jiwa bisa berupa depresi, kecemasan dan skizofrenia. Terapi psikoedukasi ini bisa berupa pasif psikoedukasi seperti pemberian informasi dengan leaftlet atau melalui email atau website dan juga bisa berupa aktif psikoedukasi berupa konseling atau pemberian pendidikan kesehatan secara individu atau kelompok (Donker 2009 dalam Suryani et al, 2016).

Menurut penelitian Kuswita dan Jaji (2013), tentang Pengaruh Psikoedukasi Terhadap Tingkat Kecemasan Pada Pasien Kanker
Payudara di RSUP Dr. Mohammad Hoesein Palembang. Berdasarkan hasil penelitian menunjukkan bahwa ada pengaruh secara signifikan sebelum dan sesudah diberikan psikoedukasi terhadap tingkat kecemasan pasien kanker payudara di RSUP Dr. Mohammad Hoesein Palembang dengan $p$-value $=0,000$ dengan nilai $\alpha=0,05(p<\alpha)$.

Hasil wawancara (pre-survey) di Ruang Mawar RSUD Dr. H. Abdul Moeloek Provinsi Lampung tempat penelitian di dapatkan dari 8 orang pasien yang akan melakukan operasi kanker payudara mengatakan cemas akan tindakan operasi yang akan dilakukan dan cemas akan efek samping dari tindakan tersebut,maka perlu dilakukanlah penelitian tentang pengaruh psikoedukasi terhadap tingkat kecemasan pasien pre operasi kanker payudara di RSUD Dr. H. Abdul Moeloek Provinsi Lampung 2018

\section{METODE}

Jenis penelitian ini menggunakan penelitian kuantitatif. Metode penelitian ini menggunakan metode penelitian quasy-eksperiment. Rancangan penelitian ini menggunakan rancangan penelitian One Group pre-test post-test.

Populasi dalam penelitian ini adalah seluruh pasien pre operasi kanker payudara yang akan menjalani operasi di RSUD H. Abdul Moeloek Provinsi Lampung. Jumlah populasi selamaSeptember 2017 sampai dengan Februari tahun 2018 sebanyak 331 orang.Penelitian ini dilaksanakan di Ruang Mawar RSUD H. Abdul Moeloek Provinsi Lampung. Pengambilan sampel secara purposif dan besarnya sampel menggunakan rumus estimasi proporsi didapatkan 30 sampel.

Instrument yang akan digunakan dalam penelitian ini adalah kuesioner. Kuesinoer yang digunakan ini, menggunakan kuesioner ZSRAS Terdapat 20 pertanyaan, dimana setiap pertanyaan dinilai 1-4 (1: tidak pernah/ sedikit, 2: kadang-kadang, 3: cukup sering, 4: hampir sering/selalu). Terdapat 20 pertanyaan diantaranya 15 pertanyaan kearah peningkatan kecemasan dan 5 pertanyaan kearah penurunan kecemasan.

Cara Pengumpulan data yaitu calon responden yang sesuai dengan kriteria yang telah ditetapkan lalu peneliti menjelaskan kepada calon responden prosedur apa yang akan dilakukan dalam penelitian ini, jika calon responden bersedia menjadi responden maka calon peserta responden mennandatangani informed consent dan peneliti memberikan kuesioner data 
demografi pasien dan kuesioner pre-test ZSRAS untuk mengukur tingkat kecemasan responden. Setelah dilakukan penilaian kuesioner pre-test ZSRAS peneliti melakukan psikoedukasi sesuai SOP kepada responden dan memberikan informasi mengenai terapi spiritual kemudian menannyakan kembali kepada klien tentang materi yang sudah diberikan. Sesudah diberikan psikoedukasi selanjutnya peneliti memberikan kuesioner post-test ZSRAS. Kemudian memperagakan kembali terapi spiritual dengan cara berdzikir bila kecemasan datang kembali lagi.

\section{HASIL}

\section{Karakteristik Responden}

Karakteristik responden berdasarkan umur, pekerjaan, pendidikan, dan pengalaman operasi sebagai berikut: responden terbanyak berusia 36-45 tahun (usia dewasa akhir) yaitu 10 responden $(33,3 \%)$. Dilihat dari pekerjaan responden dalam penelitian ini didapatkan bahwa yang terbanyak adalah bekerja sebagai IRT yang berjumlah 15 responden (50\%). Lalu dilihat dari jenjang pendidikan didapatkan bahwa yang terbanyak adalah lulusan SMA dengan jumlah 16 responden $(53,3 \%)$. Kemudian dilihat dari pengalaman operasi yang terbanyak adalah tidak pernah menjalankan operasi sejumlah 25 responden $(83,3 \%)$. Tingkat pendidikan, pekerjaan, dan pengalaman operasi sebelumnya mempengaruhi perasaan cemas seseorang pasien yang akan menjalankan operasi. Pada penelitian ini sebagian besar responden berpendidikan SMA $(53,3 \%)$, jenis kelamin perempuan (100\%), pekerjaan ibu rumah tangga $(50 \%)$, rata rata usia 45 tahun $(16,7 \%)$, dan pengalaman operasi $(83,3 \%)$.

Tabel 1. Kecemasan Ibu Pre Operasi Kanker Payudara Sebelum dan Sesudah Diberikan Psikoedukasi

\section{Psikoedukasi Kecemasan}

\begin{tabular}{lccccc} 
& \multicolumn{1}{c}{ n } & Mean & Median & SD & Min-Max \\
\hline Sebelum & 30 & 47,93 & 51 & 8,329 & $30-31$ \\
\hline Sesudah & 30 & 40,53 & 42 & 6,334 & $27-49$ \\
\hline
\end{tabular}

Tabel 1 Menjelaskan hasil pengukuran rata-rata kecemasan pada pasien pre operasi kanker payudara sebelum diberikan psikoedukasi adalah mean 47,93 dengan standar deviasi 8,329, kecemasan terendah adalah 30 dan kecemasan tertinggi adalah 61. Pengukuran rata-rata kecemasan pada pasien pre operasi kanker payudara sesudah diberikan psikoedukasi adalah mean 40,53 dengan standar deviasi 6,334, kecemasan terendah 27 dan kecemasan tertinggi 49.

Tabel 2. Perbedaan Kecemasan Ibu Preoperasi Kanker Payudara Sebelum dan Sesudah Diberikan Psikoedukasi

\begin{tabular}{lccc}
\hline Kecemasan & n & Mean & SD \\
\hline Sebelum psikoedukasi & 30 & 47,93 & 8,329 \\
\hline Sesudah psikoedukasi & 30 & 40,53 & 6,334 \\
\hline$p$-value & \multicolumn{3}{c}{0,000} \\
\hline
\end{tabular}

Tabel 2 menjelaskan bahwa rata-rata indeks kecemasan pre operasi sebelum diberikan terapi psikoedukasi adalah 47,93. Pada pengukuran distribusi rata-rata kecemasan setelah diberikan terapi dukungan psikoedukasi didapatkan rata-rata kecemasan 40,53. Nilai perbedaan mean antara kecemasan sebelum dan sesudah diberikan terapi psikoedukasi adalah 7,4. Hasil ststistik dengan uji Wilcoxon Signed Ranks Test didapatkan hasil $p$-value sebesar $(0,000)<\alpha$ $(0,05)$, hal ini menunjukkan ha diterima yang artinya terapi psikoedukasi memiliki pengaruh dalam menurunkan tingkat kecemasan pada pasien preoperasi.

\section{PEMBAHASAN}

\section{Perbedaan Kecemasan}

Berdasarkan hasil penelitian yang telah dilakukan pada pasien pre operasi kanker payudara di Ruang Mawar RSUD Dr. H. Abdul Moeloek Provinsi Lampung didapatkan bahwa responden terbanyak berusia 36-45 tahun (usia dewasa akhir) yaitu 10 responden (33,3\%).Dilihat dari pekerjaan responden dalam penelitian ini didapatkan bahwa yang terbanyak adalah bekerja sebagai IRT yang berjumlah 15 responden (50\%). Lalu dilihat dari jenjang pendidikan didapatkan bahwa yang terbanyak adalah lulusan SMA dengan jumlah 16 responden (53,3\%). Kemudian dilihat dari pengalaman operasi yang terbanyak adalah tidak pernah menjalankan operasi sejumlah 25 responden $(83,3 \%)$.

Tingkat pendidikan, pekerjaan, dan pengalaman operasi sebelumnya mempengaruhi perasaan cemas seseorang pasien yang akan menjalankan operasi. Pada penelitian ini sebagian besar responden berpendidikan SMA $(53,3 \%)$, jenis kelamin perempuan (100\%), pekerjaan ibu rumah tangga $(50 \%)$, rata rata usia 45 tahun $(16,7 \%)$, dan pengalaman operasi $(83,3 \%)$. Tidak ada hubungan antara jenis kelamin dan umur dengan tingkat kecemasan, teori ini bertentangan dengan Smeltzer \& Bare (2002) yang menyatakan 
bahwa individu yang memiliki kematangan kepribadian lebih sukar mengalami gangguan akibat kecemasan, karena individu 14 yang matur memiliki daya adaptasi yang lebih besar terhadap kecemasan.

Menurut peneliti umur, pekerjaan, pendidikan, dan pengalaman operasi itu menentukan tingkat kecemasan seseorang karena dengan umur yang lebih matang klien bisa berfikir secara dewasa. Semakin tinggi pendidikan seseorang mempengaruhi karena semakin tinggi pendidikan seseorang, semakin baik mekanisme koping yang digunakan. Pekerjaan pun mempengaruhi karena faktor besar dari kecemasan adalah tentang finansial, dimana yang kita tahu biaya pengobatan dirumah sakit tidaklah murah. Pengalaman operasi sangat berpengaruh jika belum menjalani operasi pasien biasanya berfikir negatif. Pengaruh psikoedukasi terhadap tingkat kecemasan pasien pre operasi kanker payudara.

Hasil penelitian ini diperoleh data distribusi rata rata kecemasan sebelum dilakukan terapi psikoedukasi dengan hasil 47,93, standar deviasi 83,29, nilai minimum 30, dan skor maksimum 61. Dimana 47,93 masuk dalam kategori kecemasan sedang (45-59). Setelah dilakukan terapi psikoedukasi tampak adanya penurunan distribusi rata- rata, hasil penelitian ini diperoleh data distribusi rata-rata kecemasan responden setelah dilakukan terapi psikoedukasi dengan hasil 40,53, standar deviasi 6,334 , nilai minimum 27, dan nilai maksimum 49. Secara kuantitatif penelitian ini bermakna karena menunjukakan adanya perbedaan skor kecemasan sebelum dan sesudah dilakukan terapi psikoedukasi. Rata rata kecemasan berkurang menjadi 40,53 termasuk kecemasan ringan (2044).

Hasil analisis bivariat penelitian yang telah dilakukan dengan menggunakan uji Wilcoxon Signed Ranks Testdiperoleh hasil $(0,000)<\alpha$ $(0,05)$ yang berarti $H_{0}$ ditolak, sehingga dapat disimpulkan bahwa melakukan psikoedukasi berpengaruh terhadap penurunan tingkat kecemasan pasien pre operasi kanker payudara di RSUD Dr. H. Abdul Moeloek Provinsi Lampung 2018.

Menurut Smeltzer and Bare (2002) pendekatan suportif, dukungan emosi dari keluarga dan orang terdekat akan memberi kita cinta dan perasaan berbagai beban. Kemampuan berbicara kepada seseorang dan mengekspresikan perasaan secara terbuka dapat membantu dalam menguasai keadaan. Penatalaksanaan keperawatan mandiri berdasarkan Nursing Intervention Classification (NIC) yang dianjurkan untuk tindakan menurunkan kecemasan yaitu penurunan kecemasan, teknik menenangkan, pengembangan mekanisme koping, pendampingan pasien, kehadiran perawat dan konseling lewat telpon. Salah satunya psikoedukasi sering juga disebut personal and social education atau pendidikan pribadi dan sosial merupakan gerakan yang relatif baru namun penting dilingkungan psikologi konseling. Hakikat gerakan ini adalah perluasan peran konselor melampaui aktivitas pemberian layanan konseling individual dan kelompok secara tradisional (Supratiknya, 2008).

Soep (2009) dalam Umaroh \& Rosa (2017) menyatakan bahwa psikoedukasi adalah salah satu bentuk tindakan keperawatan kesehatan jiwa dengan cara pemberian informasi dan edukasi melalui komunikasi yang teraupetik. Manfaat dari pemberian psikoedukasi dapat membantu mengatasi kecemasan, membuat perasaan menjadi lebih baik dan dapat membantu memecahkan masalah yang dihadapi, mengurangi depresi dan menumbuhkan rasa percaya diri.

Menurut Potter (2006), reaksi pasien terhadap pembedahan didasarkan pada banyak faktor, meliputi ketidaknyamanan dan perubahanperubahan yang diantisipasi baik fisik, finansial, psikologis, spiritual, sosial, atau hasil akhir pembedahan yang diharapkan. Kecemasan dapat menimbulkan adanya perubahan secara fisik maupun psikologis yang akhirnya mengaktifkan saraf otonom simpatis sehingga meningkatkan denyut jantung, peningkatan tekanan darah, peningkatan frekuensi nafas dan secara umum mengurangi tingkat energi pada pasien, dan akhirnya dapat merugikan individu itu sendiri.

Hasil penelitian ini menyatakan bahwa terapi psikoedukasi dapat menurunkan tingkat kecemasan pasien pre operasi kanker payudara. Rumah sakit belum menerapkan pendekatan psikologi terhadap pasien. Rumah sakit memberikan edukasi saja tanpa melakukan pendekatan psiokologi. Dengan melakukan psikoedukasi kepada pasien dapat meningkatkan pengetahuan dan meningkatkan koping yang kuat untuk menghadapi operasi. Dalam pelaksanaan psikoedukasi pasien mengungkapkan semua yang mereka rasakan, dan mengetahui apa yang menggangu pikiran pasien.

Dalam pelaksanaan psikoedukasi, memberikan motivasi kepada pasien dan kepada keluarga. penelitian ini sejalan dengan penelitian yang dilakukan Kuswita \& Jaji (2013) yang berjudul pengaruh psikoedukasi terhadap tingkat kecemasan pada pasien kanker payudara di RSUP Dr. Mohammad Hoesein Palembang. Hasil uji statistik dengan menggunakan uji paired 
samples $t$-test didapatkan $p$-value $=0,0000$ dengan nilai $a=0,05(p<a)$, berati ada pengaruh secara signifikan sebelum dan sesudah diberikan psikoedukasi terhadap tingkat kecemasan pasien kanker payudara.

Penelitian lain yang mendukung adalah penelitian yang dilakukan oleh Sriwaty \& Nuryoto (2015) menunjukkan bahwa kelompok eksperimen diperoleh hasil yang signifikan dengan nilai $p=0,027 \quad(p<0,05)$ dan nilai $\mathrm{Z}$ sebesar -2,207 sementara pada kelompok kontrol menunjukkan hasil yang tidak signifikan dengan nilai $p=0,102(p>0,5)$ dan nilai $Z$ sebesar $-2,303$. Kesimpulannya pemberian psikoedukasi menopause dan relaksasi dapat menurunkan kecemasan pada wanita pre menopause.

Sedangkan penelitian lain yang mendukung adalah penelitian yang dilakukan oleh Riwayati \& Hidayati (2015), efektifitas psikoedukasi terhadap kemampuan keluarga merawat anggota keluarga penderita HIV-AIDS Di Wilayah Kota Semarang. Hasil uji statistik menunjukkan hasil signifikan kemampuan keluarga setelah dilakukan psikoedukasi ( $p$ value $=0,000 ; \alpha=0,05)$. Itu berarti tindakan psikoedukasi kepada keluarga dengan HIV-AIDS bisa diterapkan untuk perawatan kesehatan apapun agar terciptanya Indonesia bebas HIVAIDS

Tentang pengaruh psikoedukasi untuk menurunkan tingkat kecemasan hal ini dikarenakan pemberian psikoedukasi mengenai perubahan perubahan yang dialami selamahidup dan bersikap terbuka kepada orang lain, serta menggunakan koping yang efektif dapat membantu mengurangi kecemasan pada pasien kanker payudara, membuat perasaan menjadi lebih baik dan dapat membantu memecahkan masalah yang dihadapi, mengurangi depresi dan menumbuhkan percaya diri.

Menurut peneliti, banyak sekali pasien yang mengalami kecemasan terhadap penyakit yang dideritany, kurangnya informasi dan pengetahuan membuat pasien berfikir negatif, sehingga pasien menjadi cemas dan putus asa terhadap kesembuhannya. Dilakukannya psikoedukasi memberikan rasa yang tenang dan santai untuk seseorang yang merasa tidak tenang, cemas, dan kurang pengetahuan. Menurut peneliti, terapi psikoedukasi dapat diberikan kepada pasien pre operasi untuk menurunkan kecemasan. saat ini rumah sakit belum terprogram, dengan hasil perbedaan yang cukup baik diharapkan RSUD Dr. H. Abdul Moeloek dapat menyusun program untuk melaksanakan psikoterapi sebagai bagian bagian dari asuhan keperawatan pasien pre operasi. Jika dilihat dari analisa bivariat dapat disimpulkan terdapat pengaruh terapi psikoedukasi terhadap tingkat kecemasan pada pasien pre operasi kanker payudara di RSUD Dr. H. Abdul Moeloek provinsi Lampung.

Terapi psikoedukasi ini merupakan bentuk asuhan keperawatan yang holistik. Dalam prinsip dan pelaksanaan terapi psikoedukasi menunjukkan kepedulian yang dapat membuat pasien menjadi percaya, tenang dan nyaman sehingga mendekatkan hubungan terapeutik. Terapi psikoedukasi bagi perawat masuk dalam prinsip etika keperawatan yaitu menjaga kerahasiaan klien (confidentiality) yaitu informasi tantang klien harus dijaga privasi klien. Dokumentasi tentang keadaan kesehatan klien hanya bisa dibaca guna keperluan pengobatan dan peningkatan kesehatan klien. Diskusi tentang klien diluar area pelayanan harus dihindari. Terapi psikoedukasi pun bisa dipadukan dengan terapi modalitas ataupun relaksasi yang merupakan intervensi keperawatan dalam pemberian asuhan keperawatan pada pasien yang mengalami kecemasan pre operasi kanker payudara.

\section{SIMPULAN}

1. Kecemasan responden sebelum dilakukan terapi psikoedukasi adalah 47,93 di RSUD Dr. H. Abdul Moeloek Provinsi Lampung.

2. Kecemasan responden setelah dilakukan terapi psikoedukasi 40,53 di RSUD Dr. H Abdul Moeloek Provinsi Lampung.

3. Terdapat perbedaan kecemasan sebelum dilakukan terapi psikoedukasi 47,93 dan setelah dilakukan terapi psikoedukasi 40,53 dengan $p$-value 0,000 ( $p$-value $<0,05)$ pada pasien pre operasi di RSUD Dr. H. Abdul Moeloek Provinsi Lampung.

\section{DAFTAR PUSTAKA}

Dinas Kesehatan Provinsi Lampung. (2015). Profil Kesehatan Provinsi Lampung Tahun 2014. Lampung.

Dyanti, G. A. R., \& Suariyani, N. L. P. (2016). Faktor-Faktor Keterlambatan Penderita Kanker Payudara dalam Melakukan Pemeriksaan Awal ke Pelayanan 
Kesehatan. Jurnal Kesehatan Masyarakat, 11(2), 276-284.

Kuswita, P., \& Jaji, J. (2013). Pengaruh psikoedukasi terhadap tingkat kecemasan pada pasien kanker payudara di RSUP dr. Mohammad Hoesin Palembang tahun 2013. Jurnal Keperawatan Bina Husada, 1(2), 374-379.

Maretna, T. (2018). Identifikasi Pola Polimorfisme Gen CYP1A1 (3801T/C) pada Karsinoma Payudara Invasif. (Tesis, Uniersitas Sumatera Utara).

Mansjoer, A, dkk. (2007). Kapita Selekta Kedokteran. Jakarta: Medica Aesculpalus, FKUI.

Potter, P. A \& Perry, A. G. (2006). Buku Ajar Fundamental Keperawatan: konsep, proses dan praktik Edisi ke-4. Jakarta: EGC.

Rasjidi, Imam. (2009). Deteksi dini pencegahan kanker pada wanita. Jakarta: Sagung Seto.

Riwayati, R., \& Hidayati, E. (2015). Efektifitas Psikoedukasi terhadap Kemampuan Keluarga Merawat Anggota Keluarga
Penderita HIV-AIDS di Wilayah Kota Semarang. Jurnal Keperawatan Jiwa, 3(1), 6-12.

Smeltzer, S.C, \& Bare, B.G. (2002). Buku Ajar Keperawatan Medikal Bedah, Terjemahan. Jakarta: EGC.

Sriwaty, I., \& Nuryoto, S. (2015). Pengaruh Psikoedukasi Menopause dan Relaksasi untuk Menurunkan Kecemasan Wanita Pre Menopause. Humanitas: Jurnal Psikologi Indonesia, 12(1), 29-38.

Supratiknya, A. (2008). Merancang Program dan Modul Psikoedukasi. Yogyakarta: Universitas Sanata Dharma.

Suryani, S., Widianti, E., Hernawati, T., \& Sriati, A. (2016). Psikoedukasi Menurunkan Tingkat Depresi, Stres dan Kecemasan pada Pasien Tuberkulosis Paru. Jurnal Ners, 11(1), 128-133.

Umaroh, Z. (2017). Efektifitas Psikoedukasi Terhadap Adaptasi Pasien Fraktur Di RSUD Jombang. (Tesis, Universitas Muhammadiyah Jogjakarta). 